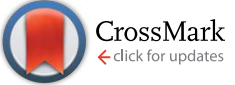

Cite this: RSC Adv., 2017, 7, 3599
Received 23rd October 2016 Accepted 13th November 2016

DOI: $10.1039 / c 6 r a 25684 h$

www.rsc.org/advances

\title{
Silver nanoparticles supported on zirconia-ceria for the catalytic wet air oxidation of methyl tert-butyl ether
}

\author{
Z. Guerra-Que, ${ }^{a}$ G. Torres-Torres, ${ }^{a}$ H. Pérez-Vidal, ${ }^{* a}$ I. Cuauhtémoc-López, ${ }^{a}$ \\ A. Espinosa de los Monteros, ${ }^{a}$ Jorge N. Beltramini ${ }^{\mathrm{b}}$ and D. M. Frías-Márquez ${ }^{\mathrm{c}}$
}

\begin{abstract}
In this work Ag nanoparticles supported on $\mathrm{ZrO}_{2}-\mathrm{CeO}_{2}$ promoted with different amounts of $\mathrm{CeO}_{2}(0,0.5,1$, $5,10,15$ and $20 \mathrm{wt} \%$ ) were synthesized by deposition-precipitation method in order to test the Catalytic Wet Air Oxidation (CWAO) of Methyl Tert-Butyl Ether (MTBE). X-ray diffraction patterns reveal that the tetragonal $\mathrm{ZrO}_{2}$ phase $\left(\mathrm{t}-\mathrm{ZrO}_{2}\right)$ present in the catalysts is stabilized by the presence of $\mathrm{CeO}_{2}$, forming a solid solution, and preventing transformation to the monoclinic phase $\left(\mathrm{m}-\mathrm{ZrO}_{2}\right)$. The $\mathrm{t}-\mathrm{ZrO}_{2}$ stability and the dispersion of $\mathrm{Ag}$ on $\mathrm{ZrO}_{2}$ increase with $\mathrm{CeO}_{2}$ concentration. HRTEM images confirmed that the mean crystallite size of supports and monometallic $\mathrm{Ag}$ catalyst decreases by $\mathrm{CeO}_{2}$ addition. $\mathrm{CeO}_{2}$ can also improve the reduction of $\mathrm{Ag}_{2} \mathrm{O}$ and increase also the d-electron density of the surface silver atoms. Furthermore, $\mathrm{CeO}_{2}$ has a promoting effect on silver supported zirconia-ceria because of the strong metal-support interaction and its relationship of oxygen vacancies of zirconia-ceria support. The extent of reduction of silver controls the quantity of oxygen to be adsorbed during the catalytic oxidation reaction. In general, a small crystal size and high metallic dispersion can enhance the activity of MTBE catalytic wet air oxidation. The $\mathrm{Ag} / \mathrm{ZrO} 2-(15 \%) \mathrm{CeO}_{2}$ catalyst was the most active with $90 \% \mathrm{MTBE}$ conversion.
\end{abstract}

\section{Introduction}

At present, concern about the treatment of generated pollutants discarded into the groundwater has increased in world chemical industries such as petrochemicals. This wastewater can present a potentially harmful impact on both the environment and humans, when quantities exceed the limits permitted per day and even more if they are untreated or the treatment is inadequate. ${ }^{1-3}$ The composition and concentration of wastewater depend on operating conditions of the industrial process but they certainly contain both organic matter and toxic pollutants of different molecular weights. Contaminants can be simple such as acetic acid or complex such as polymers. Within the group of organic pollutants, there are those called refractories, characterized for being non-biodegradable, remaining in a certain concentration even in treated water and for being highly toxic, hence its importance. ${ }^{4}$ Conventional

${ }^{a}$ Universidad Juárez Autónoma de Tabasco, Laboratorio de Catálisis Heterogénea, Área de Química, DACB, Km. 1 Carretera Cunduacán-Jalpa de Méndez A.P. 24, Cunduacán, C.P. 86690, Tabasco, Mexico. E-mail: hermicenda.perez@ujat.mx; Fax: +52 19143360928; Tel: +5219143360300

${ }^{b} A R C$ Centre of Excellence for Functional Nanomaterials, The Australian Institute for Bioengineering and Nanotechnology, School of Engineering, The University of Queensland, St. Lucia, QLD 4072, Australia

${ }^{c}$ Universidad Juárez Autónoma de Tabasco, DAIA, Km. 1 Carretera Cunduacán-Jalpa de Méndez, Col. La Esmeralda, Cunduacán, C.P. 86690, Tabasco, Mexico physicochemical methods are inefficient for the treatment of effluents containing this type of compounds, as they do not destroy them completely and this can result in even more toxic intermediates than the initial compounds. Biological treatment has been used as an alternative, which is an economical method to treat this type of wastewater., ${ }^{5,6}$ Lot of bacteria have been reported to treat organic contaminants dissolved in waste effluents, however in some cases as in wastewater from oil industry it has not shown the desired effectiveness, because this wastewater has a high content of $\mathrm{NaCl}$, and this directly affects the microorganisms responsible of the treatment, inhibiting microbial growth. ${ }^{\mathbf{1 , 4}, 7}$ Within refractory organic molecules there is the Methyl Tert-Butyl Ether (MTBE). MTBE is used as an octane gasoline enhancer additive that is presumably important for reducing air pollution by decreasing carbon monoxide emanating from car exhausts. Unfortunately, this additive has been found present in groundwater and surface water due to leakages from car or underground fuel tanks creating a serious environmental problem due to its refractory properties to degrade when releases into the environment..$^{8-11}$

In search of a suitable and efficient method to degrade MTBE, there have been many applications of advanced oxidation processes with very promising results. Within this technology is found the Catalytic Wet Air Oxidation (CWAO). ${ }^{\mathbf{1 2 - 1 7}}$

CWAO it is regarded one of the most important industrial processes to destroy hazardous, toxic and non-biodegradable 
organic compounds present in wastewater streams. The process involves the use of a tickle-bed or slurry reactors operating at temperatures in the range of $100-325^{\circ} \mathrm{C}$ at $5-200$ bar pressures, with oxygen as oxidant agent. ${ }^{14-16,18,19}$

For long catalytic oxidation reactions have shown a positive effect controlling and decreasing the pollutant concentration found in air and water sources. On this regard, silver supported catalysts have shown an excellent behavior for this reaction. Silver as a metal noble has special features to improve catalytic oxidation reactions. It is known silver can chemisorb $\mathrm{O}_{2}{ }^{20}$ silver can also catalyze $\mathrm{CO}$ oxidation, although at higher temperatures than gold. ${ }^{21,22}$ Studies on selective catalytic reduction (SCR) of $\mathrm{C}_{3} \mathrm{H}_{6}$ over $\mathrm{Ag} / \mathrm{Al}_{2} \mathrm{O}_{3}$ catalyst has shown that not only the silver content is important but also the presence of different $\mathrm{AgO}$ species as a result of pretreatment with $\mathrm{O}_{2}$ at $500{ }^{\circ} \mathrm{C}$ are essential for the selective reduction and improved conversion of $\mathrm{C}_{3} \mathrm{H}_{6} \cdot{ }^{23}$ Similar behavior was reported by Zhenping et al. ${ }^{24}$ Oxygen chemisorption on silver surface as a pretreatment generates various oxygen species such as bulk-oxygen $\left(\mathrm{O}_{\beta}\right)$ and subsurface oxygen $\left(\mathrm{O}_{\gamma}\right)$, which are responsible of the higher catalytic activity in hydrocarbon, formaldehyde (methanal) and soot oxidation. ${ }^{24-26}$ On the other hand, ceria with its ability to store and release oxygen, plays an important role in catalysis, participating directly in the conversion of environmentally sensitive molecules such as phenol and acetic acid into carbon dioxide, water and/or intermediate products. Ceria as a support has oxygen storage capacity (OSR) and redox properties. Oxygen reducibility and oxygen storage capacity seem to be important properties for the performance of ceria in oxidation reactions. ${ }^{27}$ These properties originated from its easy creation and diffusion of oxygen vacancies, especially at the support surface level. It was established that the extraction of an oxygen vacancy is associated with a reduction of Ce(Iv) species to $\mathrm{Ce}(\mathrm{III}){ }^{\mathbf{2 8 , 2 9}}$ Then the lattice of ceria compensates the anion vacancy with this charge conversion enhancing its catalytic oxidation properties. Rare earth metals and transition metals were also frequently employed for this purpose. ${ }^{30,31}$ Another important factor is played by the diffusion rate of oxygen; consequently, it is important to enhance this property. It was also found that the tetragonal phase of zirconia oxide that is thermally stable at high temperatures plays an important role on oxidation reactions due to its high oxygen ion conductivity properties. ${ }^{26,32}$ The critical step in the effective development of CWAO is the preparation of an efficient and durable catalyst. Therefore, this paper deals with the study of the catalytic properties of $\mathrm{Ag}$ supported on $\mathrm{ZrO}_{2}-\mathrm{CeO}_{2}$ for the catalytic wet oxidation degradation of MTBE using a batch reactor unit. The synergistic effect of metal and support on the reaction is also reported.

\section{Experimental}

\section{Supports preparation}

The zirconia $\left(\mathrm{ZrO}_{2}\right)$ and zirconia $\left(\mathrm{ZrO}_{2}-\mathrm{CeO}_{2}\right)$ supports were prepared by the sol gel method. The $\mathrm{ZrO}_{2}$ support was prepared using zirconia $n$-butoxide (Aldrich) as precursor. A mixture of $n$ butanol-water was stirred and kept in reflux at $80^{\circ} \mathrm{C}$. Zirconia $n$ butoxide was added drop by drop for 3 hours to this solution until a gel was formed. The mixture was constantly stirred for 24 hours at $80{ }^{\circ} \mathrm{C}$. After the water and alcohol remaining were eliminated by the use of a Rotavapor unit. Then the powder obtained was left in an oven to dry at $120^{\circ} \mathrm{C}$ for 12 hours. The samples were calcined at $500{ }^{\circ} \mathrm{C}$ for 12 hours with heating ramp of $4{ }^{\circ} \mathrm{C}$ minute ${ }^{-1}$.

The $\mathrm{ZrO}_{2}-\mathrm{CeO}_{2}$ supports were obtained by using cerium nitrate precursor salt (from Aldrich). Cerium aqueous solutions were obtained by the stoichiometric addition of precursor to obtain 0.5, 1, 5, 10, 15 and $20 \mathrm{wt} \% \mathrm{CeO}_{2}$. For $\mathrm{ZrO}_{2}-\mathrm{CeO}_{2}$ the same methodology used to obtain the $\mathrm{ZrO}_{2}$ without cerium was followed and the precursor salt was added to then-butanolwater mixture before adding it to the solution of zirconia $n$ butoxide-water.

\section{Catalyst preparation}

The Ag supported catalysts were prepared by depositionprecipitation method (DP) of $\mathrm{ZrO}_{2}$ and $\mathrm{ZrO}_{2}-\mathrm{CeO}_{2}$ supports adding the appropriated amounts of an aqueous solution containing silver nitrate $\left(\mathrm{AgNO}_{3}\right)$ to obtain a nominal concentration of $1.4 \%$ of $\mathrm{Ag}$. First $\mathrm{ZrO}_{2}$ and $\mathrm{ZrO}_{2}-\mathrm{CeO}_{2}$ support was wetted by distilled water in a beaker in order to have high dispersion and to maximize the mass transfer of added metal salt $\left(\mathrm{AgNO}_{3}\right.$, Baker, $99.8 \%$ ) on the surface and the pores of the catalyst. Subsequently, $\mathrm{NaOH}$ was added drop wise to the resulting solution under constant stirring to get a $\mathrm{pH}$ of 10 . The samples were dried at $120^{\circ} \mathrm{C}$ for 12 hours and then calcined under air flow $\left(60 \mathrm{ml} \mathrm{min}{ }^{-1}\right)$ at $300{ }^{\circ} \mathrm{C}$ for $4 \mathrm{~h}$, with a heat rate of $2{ }^{\circ} \mathrm{C}$ $\min ^{-1}$. Finally, the catalysts were reduced under $\mathrm{H}_{2}(60 \mathrm{ml}$ $\min ^{-1}$ ) at $400{ }^{\circ} \mathrm{C}$ for $4 \mathrm{~h}$, with a heat rate of $2{ }^{\circ} \mathrm{C} \min ^{-1}$.

\section{Characterization}

BET specific surface area. The surface areas of the samples were determined from the nitrogen adsorption isotherms at $-196{ }^{\circ} \mathrm{C}$ using a Micromeritics Tristar 3020 II. Prior to the analysis, the samples were outgassed at $400{ }^{\circ} \mathrm{C}$ for $4 \mathrm{~h}$. The adsorption data were analyzed using the ASAP 3020 software based on the Brunauer-Emmett-Teller (BET) isotherm.

X-ray diffraction (XRD). X-ray diffraction (XRD) was carried out using Rigaku Miniflex diffractometer employing Co $\mathrm{K} \alpha$ radiation $(\lambda=0.179 \mathrm{~nm}$ ) obtained at $30 \mathrm{kV}$ and $15 \mathrm{~mA}$ source with a scan speed of $2 \theta \mathrm{min}^{-1}$. The average crystallite size of oxide catalyst was estimated using the Scherrer equation:

$$
D=\frac{0.90 \lambda}{\beta \cos \theta}
$$

where $D$ is the crystallite size (nm), $\lambda$ is the wavelength (nm), $\beta$ is the corrected full width at half maximum (radian) and $\theta$ is the Bragg angle (radian).

DR UV-Vis spectroscopy. Diffuse reflectance UV-Vis spectra in the 900-200 $\mathrm{nm}$ range were obtained with a VARIAN 3000 spectrophotometer operating at room temperature.

Temperature programmed desorption under $\mathrm{H}_{2}$ atmosphere ( $\mathbf{H}_{2}$-TPD). $\mathrm{H}_{2}$-TPD experiments were conducted on a BELCAT equipment with thermal conductivity detector, using $0.2 \mathrm{~g}$ of catalyst. First the samples were pretreated with the following 
protocol: $20 \% \mathrm{O}_{2} / \mathrm{H}_{2}$ for $30 \mathrm{~min}$ at $400{ }^{\circ} \mathrm{C}, 20 \% \mathrm{O}_{2} / \mathrm{H}_{2}$ for $1 \mathrm{~min}$ at $35{ }^{\circ} \mathrm{C}$, He for $60 \mathrm{~min}$ at $35{ }^{\circ} \mathrm{C}, 5 \% \mathrm{H}_{2} / \mathrm{Ar}$ for $30 \mathrm{~min}$ at $400{ }^{\circ} \mathrm{C}$, $5 \% \mathrm{H}_{2} / \mathrm{Ar}$ for $1 \mathrm{~min}$ at $35^{\circ} \mathrm{C}$ with a flow rate of $50 \mathrm{sccm}$. Then the samples were treated by Ar at $50 \mathrm{sccm}$. The temperature was raised from room temperature to $400{ }^{\circ} \mathrm{C}$ at a heating rate of $10{ }^{\circ} \mathrm{C} \min ^{-1}$. Dispersion was calculated according to $\mathrm{mmol} \mathrm{g}^{-1}$ of $\mathrm{H}_{2}$ adsorbed on each sample, metal content of silver $(1.4 \%)$ and $1: 1 \mathrm{Ag}: \mathrm{H}_{2}$ stoichiometry.

Hydrogen pulse chemisorption. Hydrogen pulse chemisorption was also conducted on the BELCAT equipment. Typically, $0.1 \mathrm{~g}$ of catalyst was reduced at $50{ }^{\circ} \mathrm{C}$ in a flow of $\mathrm{H}_{2}$ for $10 \mathrm{~min}$ and degassed with $\mathrm{Ar}$ at $50{ }^{\circ} \mathrm{C}$ for $10 \mathrm{~min}$. Hydrogen uptake was then measured at $50{ }^{\circ} \mathrm{C}$ by injecting pulses of $5 \% \mathrm{H}_{2}$ / Ar. The Ag dispersion was calculated based on $1: 1 \mathrm{Ag}: \mathrm{H}_{2}$ stoichiometry.

Transmission electron microscopy (TEM). Transmission electron microscopy (TEM) was performed in a JEOL JEM2100 STEM. Equipped with a JEOL JED2300 Energy Dispersive X-ray Analyzer (EDXS). The samples were ground, suspended in ethanol at room temperature, and dispersed with agitation in an ultrasonic bath for $15 \mathrm{~min}$, then an aliquot of the solution was passed through a carbon copper grid.

X-ray photoelectron spectroscopy (XPS). Data was acquired using a Kratos Axis ULTRA X-ray Photoelectron Spectrometer incorporating a $165 \mathrm{~mm}$ hemispherical electron energy analyzer. The incident radiation was monochromatic AlK $\alpha \mathrm{X}$ rays $(1486.6 \mathrm{eV})$ at $225 \mathrm{~W}(15 \mathrm{kV}, 15 \mathrm{~mA})$. Survey (wide) scans were taken at analyzer pass energy of $160 \mathrm{eV}$ and multiplex (narrow) high resolution scans at $20 \mathrm{eV}$. Survey scans were carried out over 1200-0 eV binding energy range with $1.0 \mathrm{eV}$ steps and a dwell time of $100 \mathrm{~ms}$. Narrow high-resolution scans were run with $0.05 \mathrm{eV}$ steps and $250 \mathrm{~ms}$ dwell time. Base pressure in the analysis chamber was $1.0 \times 10^{-9}$ torr and during sample analysis $1.0 \times 10^{-8}$ torr. Atomic concentrations were calculated using the CasaXPS version 2.3.14 software and a Shirley baseline with Kratios library Relative Sensitivity Factors (RSFs). Peak fitting of the high-resolution data was also carried out using the CasaXPS software.

\section{Activity tests}

All catalysts were tested in a high pressure stainless steel batch reactor (Parr Instruments) equipped with sampling valve, magnetic driven stirrer, gas supply system and temperature controller. The catalytic wet air oxidation reaction was carried out as follows: using a reaction volume of $300 \mathrm{ml}$ of an aqueous solution with a concentration of $440 \mathrm{ppm}$ and $1 \mathrm{~g} \mathrm{~L}^{-1}$ of monometallic catalyst. After the reactor was heated at $80^{\circ} \mathrm{C}$ to reach the desirable temperature, pure oxygen $\left(\mathrm{O}_{2}\right)$ was added under stirring. The catalysts were previously reduced at $400{ }^{\circ} \mathrm{C}$

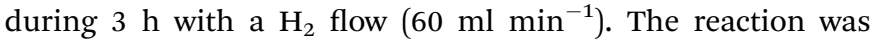
performed for $60 \mathrm{~min}$. The samples in the effluent were taken at intervals of $10 \mathrm{~min}$ through $1 \mathrm{~h}$, and the MTBE content $(C)$, intermediate content and Total Organic Carbon (TOC) were analyzed. MTBE content and intermediate content were measured with High Performance Liquid Chromatograph (HPLC). Total Organic Carbon (TOC) of the samples was measured with a TOC 5000 Shimadzu Analyzer. MTBE conversion and TOC was calculated using:

$$
\begin{gathered}
X_{\mathrm{MTBE}}=\frac{C_{0}-C_{60}}{C_{0}} \times 100 \% \\
X_{\mathrm{TOC}}=\frac{\mathrm{TOC}_{0}-\mathrm{TOC}_{60}}{\mathrm{TOC}_{0}} \times 100 \%
\end{gathered}
$$

where $\mathrm{TOC}_{0}$ is total organic carbon at $t=0(\mathrm{ppm}), C_{0}$ is the MTBE concentration at $t=0(\mathrm{ppm}), C_{60}$ is the MTBE concentration at $t=1 \mathrm{~h}$ of reaction (ppm), TOC $_{60}$ is total organic carbon at $t=1 \mathrm{~h}$ of reaction (ppm). So the selectivity was calculated according to follow equation. ${ }^{33}$

$$
S_{\mathrm{CO}_{2}}=\frac{X_{\mathrm{TOC}}}{X_{\mathrm{MTBE}}} \times 100
$$

The initial rate $\left(r_{\mathrm{i}}\right)$ was calculated from the MTBE conversion as a function of time, using the follow equation:

$$
r_{\mathrm{i}}=\left(\frac{\Delta_{\mathrm{MTBE}}(\%)}{\Delta t m_{\text {cat }}}\right)[\text { pollutant }]_{\mathrm{i}}
$$

where $\frac{\Delta_{\mathrm{MTBE}}(\%)}{\Delta t}$ is the conversion at initial time; [pollutant $]_{\mathrm{i}}=$ initial concentration of the pollutant and $m_{\text {cat }}=$ mass of catalyst $\left(\mathrm{g}_{\text {cat }} \mathrm{L}^{-1}\right)$.

\section{Results and discussion}

\section{Catalyst characterization}

Table 1 list the BET surface area of the monometallic Ag catalysts and supports. BET surface areas of the supports were found to be between $45 \mathrm{~m}^{2} \mathrm{~g}^{-1}$ and $66 \mathrm{~m}^{2} \mathrm{~g}^{-1}$, while BET surface areas of the monometallic catalysts were between $46 \mathrm{~m}^{2} \mathrm{~g}^{-1}$ and $63 \mathrm{~m}^{2} \mathrm{~g}^{-1}$ respectively. From the results it can be seen a slight decrease of the specific surface area for the monometallic catalyst. This behavior can be explained as the micropores of the support can be plugged by the silver metal nanoparticle during synthesis causing the reduction of the surface area of monometallic catalyst. However, $\mathrm{Ag} / \mathrm{ZrO}_{2}$ catalyst showed similar surface area $\left(46 \mathrm{~m}^{2} \mathrm{~g}^{-1}\right)$ than pure $\mathrm{ZrO}_{2}$ support $\left(45 \mathrm{~m}^{2}\right.$ $\left.\mathrm{g}^{-1}\right) \cdot{ }^{34-37}$

The $\mathrm{N}_{2}$ adsorption-desorption isotherms of the samples were shown in Fig. 1. Similar type IV adsorption-desorption isotherms with evident hysteresis looped at higher relative pressure $\left(P / P_{\mathrm{o}}\right)$ were observed for all samples, indicating the characteristic of mesoporous materials with ink bottle pores, as defined by IUPAC. ${ }^{\mathbf{3 8 - 4 0}}$ As also observed, hysteresis indicates the presence of capillary condensation suggesting the presence of high-strength agglomerates (aggregates). ${ }^{41}$

In Table 1 , the dispersion of monometallic $\mathrm{Ag}$ catalyst determined by hydrogen pulse chemisorption and temperature programmed desorption under $\mathrm{H}_{2}$ atmosphere is reported. It can be seen when the particle size of $\mathrm{Ag}$ metal decreases, the metallic dispersion increases. Besides, the dispersion of Ag was enhanced as ceria content increases. In the case of $\mathrm{Ag} / \mathrm{ZrO}_{2}-$ $(15 \%) \mathrm{CeO}_{2}$ and $\mathrm{Ag} / \mathrm{ZrO}_{2}-(20 \%) \mathrm{CeO}_{2}$ the calculated dispersion is 
Table 1 Physical properties of zirconia-ceria supported Ag catalyst. Average particle diameter $\left(d_{p}\right)$ and metallic dispersion $(D)$

\begin{tabular}{lllll}
\hline Support & Surface area $\left(\mathrm{m}^{2} \mathrm{~g}^{-1}\right)$ & Catalyst & Surface area $\left(\mathrm{m}^{2} \mathrm{~g}^{-1}\right)$ & $d_{\mathrm{p}}{ }^{a}(\mathrm{~nm})$ \\
\hline $\mathrm{ZrO}_{2}$ & 45 & $\mathrm{Ag} / \mathrm{ZrO}_{2}$ & 46 & 2.71 \\
$\mathrm{ZrO}_{2}-(0.5 \%) \mathrm{CeO}_{2}$ & 46 & $\mathrm{Ag} / \mathrm{ZrO}_{2}-(0.5 \%) \mathrm{CeO}_{2}$ & 43 & $43 \%$ \\
$\mathrm{ZrO}_{2}-(1 \%) \mathrm{CeO}_{2}$ & 43 & $\mathrm{Ag} / \mathrm{ZrO}_{2}-(1 \%) \mathrm{CeO}_{2}$ & 41 & $38 \%$ \\
$\mathrm{ZrO}_{2}-(5 \%) \mathrm{CeO}_{2}$ & 44 & $\mathrm{Ag} / \mathrm{ZrO}_{2}-(5 \%) \mathrm{CeO}_{2}$ & 37 & 4 \\
$\mathrm{ZrO}_{2}-(10 \%) \mathrm{CeO}_{2}$ & 46 & $\mathrm{Ag} / \mathrm{ZrO}_{2}-(10 \%) \mathrm{CeO}_{2}$ & 41 & $29 \%{ }^{a}$ \\
$\mathrm{ZrO}_{2}-(15 \%) \mathrm{CeO}_{2}$ & 45 & $\mathrm{Ag} / \mathrm{ZrO}_{2}-(15 \%) \mathrm{CeO}_{2}$ & 45 & $28 \%{ }^{a}$ \\
$\mathrm{ZrO}_{2}-(20 \%) \mathrm{CeO}_{2}$ & 66 & $\mathrm{Ag} / \mathrm{ZrO}_{2}-(20 \%) \mathrm{CeO}_{2}$ & 63 & $28 \%{ }^{b}$ \\
${ }^{2}$ & & $61 \%{ }^{b}$ & 4.2 \\
\end{tabular}

${ }^{a}$ Dispersion and particle diameter by hydrogen pulse chemisorption. ${ }^{b}$ Dispersion by hydrogen temperature programmed desorption.

higher when compared with $\mathrm{Ag} / \mathrm{ZrO}_{2}$ catalyst. This finding was associated with the metal-support interaction effect. ${ }^{27,42-44}$ The stabilization of $\mathrm{Ag}$ on $\mathrm{ZrO}_{2}-\mathrm{CeO}_{2}$ can be related to well-known phenomenon of re-dispersion of $\mathrm{Pt}$ on $\mathrm{CeO}_{2}$ where the oxygen vacancy of $\mathrm{CeO}_{2}$ plays an important role dispersing $\mathrm{Ag}$ into nanoparticle. ${ }^{45}$

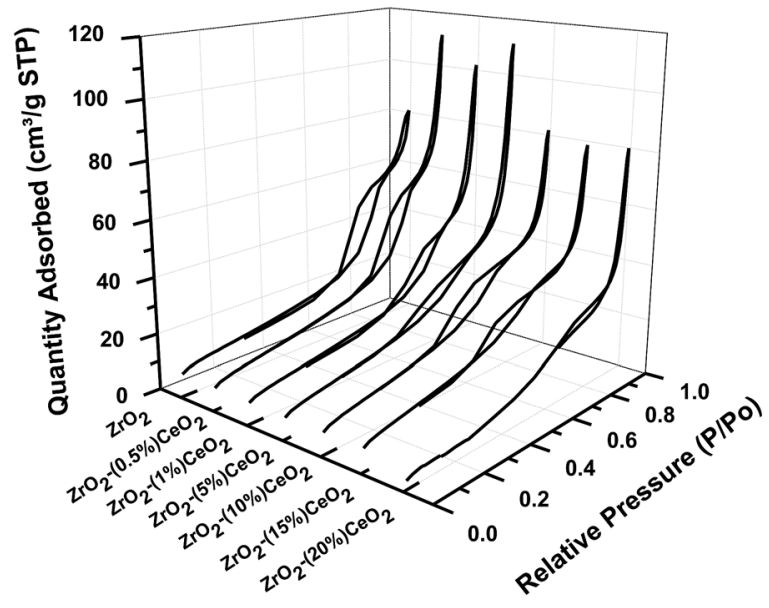

(a)

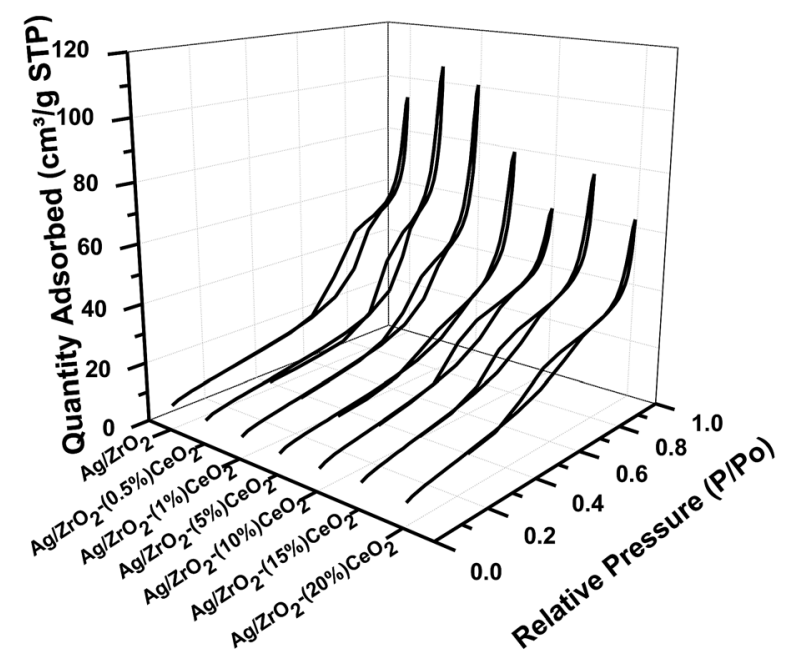

(b)

Fig. 1 Adsorption/desorption isotherms for (a) $\mathrm{ZrO}_{2}, \mathrm{ZrO}_{2}-(X \%) \mathrm{CeO}_{2}$ supports and (b) $\mathrm{Ag} / \mathrm{ZrO}_{2}, \mathrm{Ag} / \mathrm{ZrO}_{2}-(X \%) \mathrm{CeO}_{2}$ catalysts.
Fig. 2 shows the XRD spectra of the $\mathrm{ZrO}_{2}, \mathrm{ZrO}_{2}-(5 \%) \mathrm{CeO}_{2}$, $\mathrm{ZrO}_{2}-(20 \%) \mathrm{CeO}_{2}$ as well as the monometallic catalyst $\mathrm{Ag} / \mathrm{ZrO}_{2}$, $\mathrm{Ag} / \mathrm{ZrO}_{2}-(5 \%) \mathrm{CeO}_{2}, \quad \mathrm{Ag} / \mathrm{ZrO}_{2}-(20 \%) \mathrm{CeO}_{2}$. Previously cubic, tetragonal and monoclinic structures have been reported for zirconia and zirconia-ceria solid solutions. ${ }^{46-57}$ It is known that

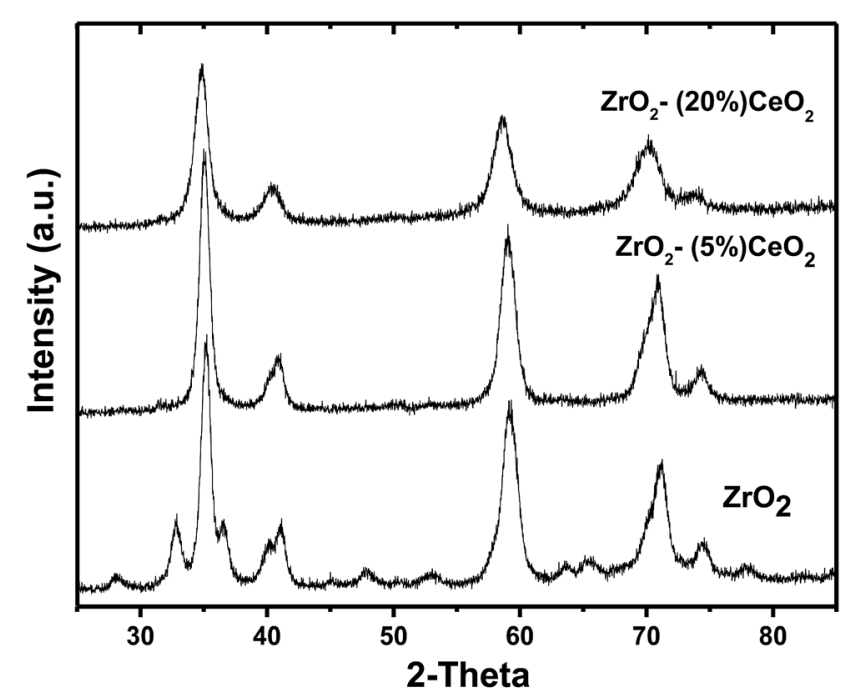

(a)

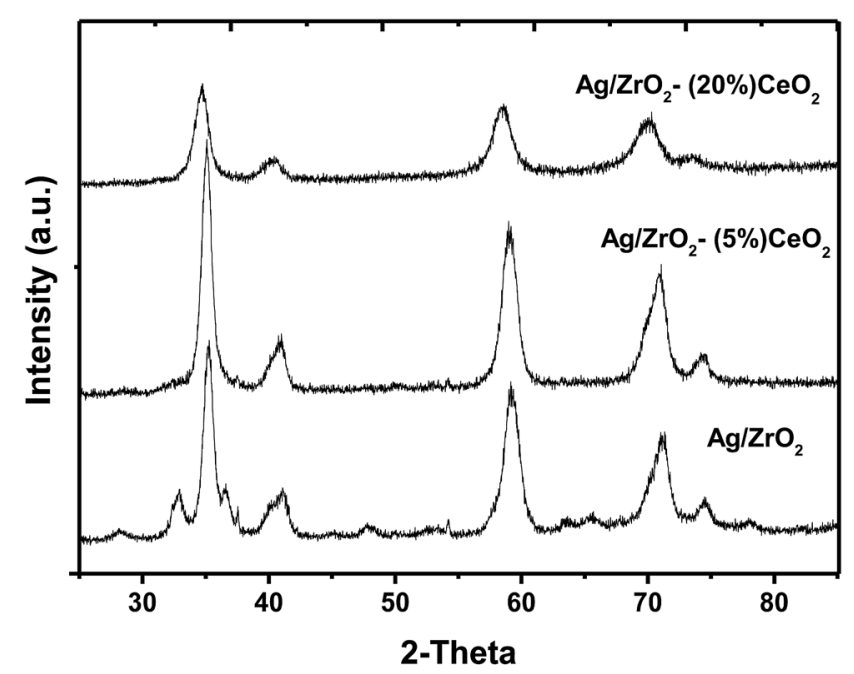

(b)

Fig. 2 X-ray diffraction patterns for (a) $\mathrm{ZrO}_{2}, \mathrm{ZrO}_{2}-(X \%) \mathrm{CeO}_{2}$ supports and (b) $\mathrm{Ag} / \mathrm{ZrO}_{2}, \mathrm{Ag} / \mathrm{ZrO}_{2}-(X \%) \mathrm{CeO}_{2}$ catalysts. 
the crystal structures of zirconia-ceria solid solutions and their structural parameters strongly depend on its chemical composition and the synthesis method. ${ }^{45,47,49,56}$ The XRD pattern of the prepared catalysts pure $\mathrm{ZrO}_{2}$ and mixed $\mathrm{ZrO}_{2}-\mathrm{CeO}_{2}$ oxides calcined at $500{ }^{\circ} \mathrm{C}$ are illustrated in Fig. 2a. Four intense peaks were found at $2 \theta=35^{\circ}, 41^{\circ}, 59^{\circ}$, and $71^{\circ}$, which corresponds with the (111), (200), (220), and (311) planes, respectively in supports and monometallic catalysts. Pure $\mathrm{ZrO}_{2}$ catalyst displayed the XRD pattern corresponding to the monoclinic phase with weak bands at about $33^{\circ}$ and $37^{\circ}$ as well as tetragonal with the main peak at $2 \theta=35^{\circ} .{ }^{46-48,51}$ The XRD pattern of mixed oxides catalysts is similar to that of pure $\mathrm{ZrO}_{2}$ and no additional peaks attributed cubic $\mathrm{CeO}_{2}$ were observed, besides, monoclinic peaks of $\mathrm{ZrO}_{2}$ were vanished, indicating that $\mathrm{CeO}_{2}$ was incorporated into the $\mathrm{ZrO}_{2}$ lattice to form solid solution and sustaining the tetragonal phase. ${ }^{46,48,54,57-59}$ The most intense lines were shifted to smaller diffraction angles with increasing $\mathrm{CeO}_{2}$ content. This observation was attributed to expansion of the lattice due to the replacement of $\mathrm{Zr}^{4+}$ (ionic radius $0.084 \mathrm{~nm}$ ) with a bigger $\mathrm{Ce}^{4+}$ (ionic radius $0.097 \mathrm{~nm}$ ). ${ }^{46,47,49,52-57}$ Solinas et al..$^{52}$ studied the effect of $\mathrm{CeO}_{2}$ addition of $\mathrm{ZrO}_{2}$ properties by XRD and found that the addition of $\mathrm{CeO}_{2}(\leq 25 \%)$ cause the formation of tetragonal structure. It is possible then pure $\mathrm{ZrO}_{2}$ is represented by a mixture of the monoclinic and tetragonal phases. Then on zirconia-ceria supports a tetragonal phase is most likely to be found than for pure $\mathrm{ZrO}_{2}$ supports. It indicated that the crystal phase remarkably changed with $\mathrm{CeO}_{2}$ added to $\mathrm{ZrO}_{2}$. Khaodee et al. ${ }^{47}$ explained the replacement of $\mathrm{Zr}^{4+}$ with larger cation such as $\mathrm{Ce}^{4+}$ could led to an increase of lattice defects.

The crystal size obtained using the Scherrer's equation (Table 2), shows that when smaller width of the peak, there is larger crystal size and vice versa. As a result, larger crystal size for $\mathrm{ZrO}_{2}(9.7 \mathrm{~nm})$ and crystal size for $\mathrm{ZrO}_{2}-(20 \%) \mathrm{CeO}_{2}(7.5 \mathrm{~nm})$ were found. So here it is demonstrated that addition of dopant ceria at high content (20\%) improved crystal growth. As a result, the sintering properties of zirconia can be modified by doping. The support zirconia-ceria is an excellent via for the formation of a mixed oxide since it generates excellent structural properties as reflected by the addition of ceria modified crystal growth.

The crystallites sizes of the mixed oxides decreased with increasing Ce content. The observation is in accordance with the BET surface area results shown in Table 1 , where $\mathrm{ZrO}_{2}-\mathrm{CeO}_{2}$ catalysts with higher Ce loading showed larger surface area than pure $\mathrm{ZrO}_{2}$ catalyst.

The XRD patterns of monometallic silver catalyst are presented in Fig. $2 \mathrm{~b}$. The introduction of $1.4 \% \mathrm{wt} \mathrm{Ag}$ did not change

Table 2 Crystal size of the $\mathrm{ZrO}_{2}$ support

\begin{tabular}{lll}
\hline Catalysts & $\begin{array}{l}\text { Crystal size by Scherrer's } \\
\text { equation }(\mathrm{nm})\end{array}$ & $\begin{array}{l}\text { Crystal size by } \\
\text { TEM }(\mathrm{nm})\end{array}$ \\
\hline $\mathrm{ZrO}_{2}$ & 9.7 & 10 \\
$\mathrm{ZrO}_{2}-(5 \%) \mathrm{CeO}_{2}$ & 9.5 & 9 \\
$\mathrm{ZrO}_{2}-(20 \%) \mathrm{CeO}_{2}$ & 7.5 & 6
\end{tabular}

the crystalline structure of $\mathrm{ZrO}_{2}$ and $\mathrm{ZrO}_{2}-\mathrm{CeO}_{2}$ supports. In addition, weak diffraction peaks of the metallic Ag were observed in almost all samples, because of the intensity of these peaks were higher on the $\mathrm{Ag} / \mathrm{ZrO}_{2}$ samples than on the $\mathrm{Ag} / \mathrm{ZrO}_{2}-$ $(X \%) \mathrm{CeO}_{2}$ catalysts; suggesting that $\mathrm{CeO}_{2}$ dopant promote the dispersion of $\mathrm{Ag}$ and make its crystallite size smaller. These transformations were all beneficial to the catalytic activity.

The UV-spectra of $\mathrm{ZrO}_{2}$ and several $\mathrm{ZrO}_{2}-(X \%) \mathrm{CeO}_{2}$ mixed oxides prepared by sol gel method are given in Fig. 3. It can be seen several absorption bands in the UV region between 200 and $400 \mathrm{~nm}$ for the supports; however, for the monometallic $\mathrm{Ag}$ catalyst the absorption bands are in the region between $200 \mathrm{~nm}$ and $600 \mathrm{~nm}$. According to the literature the band in the region between $210 \mathrm{~nm}$ and $245 \mathrm{~nm}$ could be related to the presence of $\mathrm{ZrO}_{2}$, moreover the band in the region between $260 \mathrm{~nm}$ and $380 \mathrm{~nm}$ could be related to the presence of $\mathrm{CeO}_{2} \cdot{ }^{60,61}$ The UV spectrum of $\mathrm{ZrO}_{2}$ sample shows one absorption peak at $220 \mathrm{~nm}$. According to Ranga Rao et al. ${ }^{61}$ an adsorption band at $245 \mathrm{~nm}$ means a predominantly $\mathrm{m}-\mathrm{ZrO}_{2}$ sample. When $\mathrm{CeO}_{2}$ content

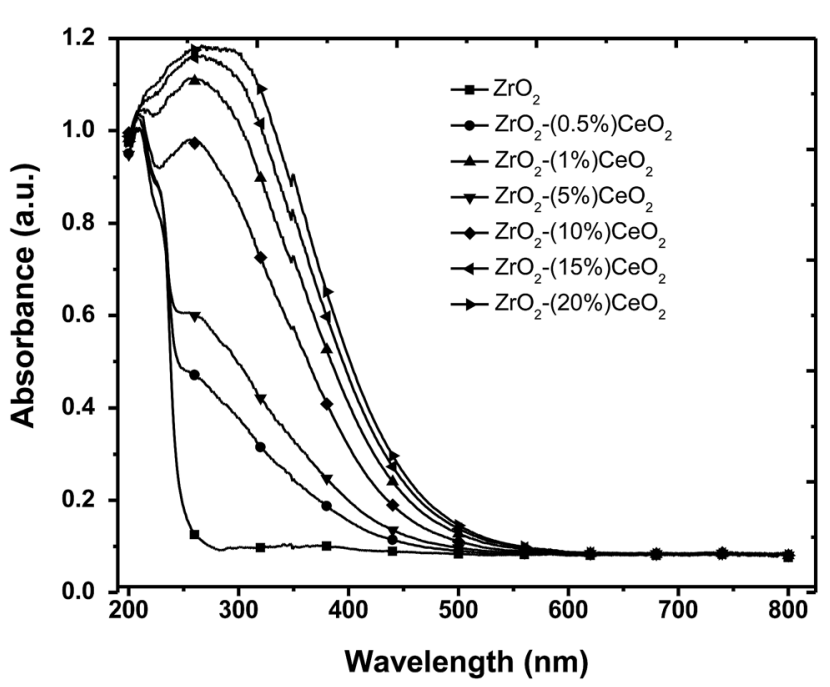

(a)

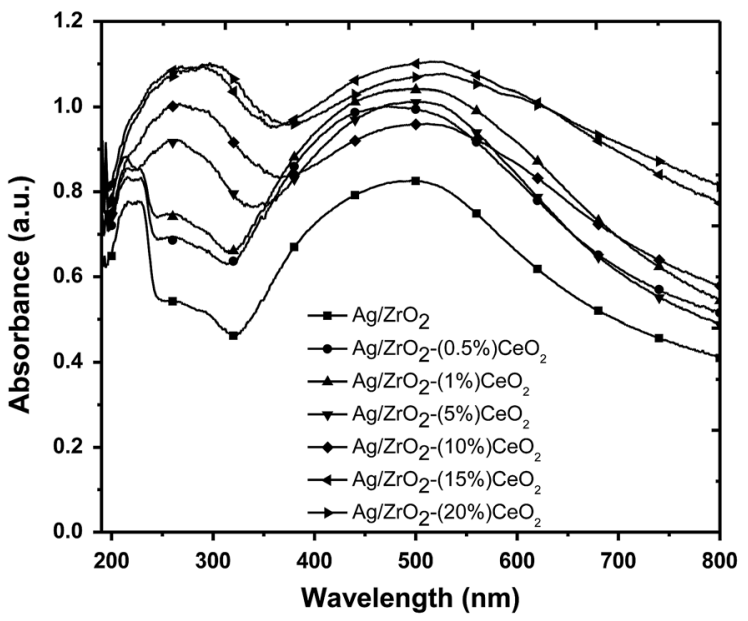

(b)

Fig. 3 Spectra UV-Vis for (a) $\mathrm{ZrO}_{2}, \mathrm{ZrO}_{2}-(X \%) \mathrm{CeO}_{2}$ supports and (b) $\mathrm{Ag} / \mathrm{ZrO}{ }_{2}, \mathrm{Ag} / \mathrm{ZrO}_{2}-(X \%) \mathrm{CeO}_{2}$ catalysts. 
increase the two intense absorption bands at $220 \mathrm{~nm}$ and $260 \mathrm{~nm}$ disappear into a very broad band. So it is interesting to note that at higher $\mathrm{CeO}_{2}$ contents, the bands become very broad with the absorption band of $\mathrm{ZrO}_{2}$ at $220 \mathrm{~nm}$ in the mixed oxides almost disappearing. This latter result is in good agreement with other studies. ${ }^{\mathbf{5 3 , 6 0 , 6 1}}$

Fig. 3 also contains the spectra for reduced $\mathrm{Ag} / \mathrm{ZrO}_{2}$, and several $\mathrm{Ag} / \mathrm{ZrO}_{2}-(\mathrm{X} \%) \mathrm{CeO}_{2}$ containing catalysts. It can be seen from this latter figure that in the case of $\mathrm{Ag} / \mathrm{ZrO}_{2}$ catalyst there is the presence of a strong absorption peak around $490 \mathrm{~nm}$ in the visible range; on the other hand, for the other $\mathrm{Ag} / \mathrm{ZrO}_{2}-(X \%)$ $\mathrm{CeO}_{2}$ samples the strong absorption peak share found between $490 \mathrm{~nm}$ and $520 \mathrm{~nm}$, showing that the band position change in each sample with increasing the metal content of ceria. This is characteristic of surface plasmon absorption corresponding to $\mathrm{Ag}^{0}$ nanoparticles, which illustrate the successful reduction of $\mathrm{Ag}_{2} \mathrm{O}$ particles. ${ }^{28,73}$ There have been several studies for silver monometallic catalyst supported showing different band position of surface plasmon absorption but in each study with different supports (Table 3). It is important to point out that the most intense plasmon absorption is for the $\mathrm{Ag} / \mathrm{ZrO}_{2}-(15 \%)$ $\mathrm{CeO}_{2}$. This finding suggests that this catalyst should contain the larger proportion of metallic silver. On other words $\mathrm{Ag} / \mathrm{ZrO}_{2}-$ (15\%) $\mathrm{CeO}_{2}$ has more abundance of $\mathrm{Ag}^{0}$ nanoparticles compared to their monometallic counterparts. This result shows better performance of chemisorption of oxygen over $\mathrm{Ag} / \mathrm{ZrO}_{2}-(15 \%)$ $\mathrm{CeO}_{2}$ and $\mathrm{Ag} / \mathrm{ZrO}_{2}-(20 \%) \mathrm{CeO}_{2}$ than the rest of catalyst. ${ }^{53}$ For oxidation reactions it is know that oxygen mobility on the catalyst metal surface will enhance the surface reaction and consequently maximize catalytic activity. Moreover, other small peak that appear at $200 \mathrm{~nm}$ in monometallic silver supported on $\mathrm{ZrO}_{2}-(\mathrm{X} \%) \mathrm{CeO}_{2}$ can be assigned to the $\mathrm{Ag}^{+}$ions to the $4 \mathrm{~d}^{10} \rightarrow$ $4 \mathrm{~d}^{9} 5 \mathrm{~s}^{1}$ transition of $\mathrm{Ag}^{+}$ions highly dispersed on the support. ${ }^{28}$

TEM measurements were carried out in order to evaluate crystal sizes and morphologies of catalyst on arbitrarily selected areas. The results of HRTEM analysis performed on both support and monometallic catalysts are presented in Fig. 4. According to Fig. 4a, c and e it can be seen that crystal size of $\mathrm{ZrO}_{2}$ is bigger than mixed oxides. Besides, the smaller crystal size indicates that $\mathrm{ZrO}_{2}-(20 \%) \mathrm{CeO}_{2}$ should have a larger total surface area than $\mathrm{ZrO}_{2}$, in agreement with BET results. ${ }^{39}$ Moreover, the crystallographic structure of catalyst was also studied by TEM electron diffraction patterns as can be seen also

Table 3 Surface plasmon adsorption of different silver supported catalysts

\begin{tabular}{|c|c|c|}
\hline Catalyst & $\begin{array}{l}\text { Adsorption } \\
\text { range (nm) }\end{array}$ & Reference \\
\hline $\begin{array}{l}\mathrm{Ag} / \mathrm{TiO}_{2} \\
\text { nanocomposites }\end{array}$ & 445 & Haibin et al. $^{73} 2008$ \\
\hline $2.2 \% \mathrm{Ag} / \mathrm{TiO}_{2}$ & 480 & Sandoval et al. ${ }^{81} 2011$ \\
\hline $\mathrm{Ag} / \mathrm{Al}_{2} \mathrm{O}_{3}$ & 425 & Zhang et al. ${ }^{23} 2008$ \\
\hline $\mathrm{Ag} / \mathrm{BaCO}_{3}$ & 390 & Zheng et al. ${ }^{63} 2012$ \\
\hline $4.5 \% \mathrm{Ag} / \mathrm{SBA}-15$ & 385 & Zheng et al. ${ }^{78} 2013$ \\
\hline $\mathrm{Ag} / \mathrm{TiO}_{2}$ & 416 & Zhang et al. ${ }^{82} 2006$ \\
\hline $\mathrm{Ag} / \mathrm{SiO}_{2}$ & 408 & Mamontov et al. ${ }^{25} 2011$ \\
\hline
\end{tabular}

on Fig. 4, whereas catalyst supports were of polycrystalline nature and did not show diffraction pattern of a cubic phase. ${ }^{62-64}$ Easily detectable agglomerated particles have been observed on $\mathrm{ZrO}_{2}-(5 \%) \mathrm{CeO}_{2}$ and $\mathrm{ZrO}_{2}-(20 \%) \mathrm{CeO}_{2}$, while on $\mathrm{ZrO}_{2}$ it is hardly notice the presence of agglomerated particles. Quinelato et $a .^{\mathbf{4 1}}$ has shown that because of the particles aggregation, the surface area could be hardly detected when it is measured by physisorption $\mathrm{N}_{2}$.

On the other hand, Fig. $4 \mathrm{~b}$, $\mathrm{d}$ and $\mathrm{f}$ show the micrographs of fresh and reduced $\mathrm{Ag} / \mathrm{ZrO}_{2}, \mathrm{Ag} / \mathrm{ZrO}_{2}-(5 \%) \mathrm{CeO}_{2}, \mathrm{Ag} / \mathrm{ZrO}_{2}-(20 \%)$ $\mathrm{CeO}_{2}$ catalysts respectively. In each case the mean particle size of silver crystal were $9 \mathrm{~nm}, 12 \mathrm{~nm}$ and $4 \mathrm{~nm}$ respectively. These results showed that crystal particles were slightly bigger than when determined by $\mathrm{H}_{2}$ chemisorption. ${ }^{21}$ Interestingly and confirming previous results, the smallest particle size was found in the sample with the highest ceria metal content. The absence of the presence of metallic silver can be explained by the strong metal-support interaction effect or either the solubilization of the silver into the support. ${ }^{64}$

The $\mathrm{ZrO}_{2}, \mathrm{ZrO}_{2}-(20 \%) \mathrm{CeO}_{2}, \mathrm{Ag} / \mathrm{ZrO}_{2}$ and $\mathrm{Ag} / \mathrm{ZrO}_{2}-(20 \%)$ $\mathrm{CeO}_{2}$ supports and catalysts were further analyzed with X-ray Photoelectron Spectra (XPS) to verify the surface composition and oxidation states of the surface elements. The oxidation states of $\mathrm{Ce}, \mathrm{Ag}, \mathrm{Zr}$ were analyzed by fitting the curves of $\mathrm{Zr}_{3 \mathrm{~d}}$, $\mathrm{Ce}_{3 \mathrm{~d}}, \mathrm{O}_{1 \mathrm{~s}}, \mathrm{Ag}_{3 \mathrm{~d}}$. Table 4 shows different values of binding energies (BEs) according to analyzed metal sample. The binding energies were determined using the $\mathrm{C} 1 \mathrm{~s}$ at $285 \mathrm{eV}$ as standard in the analysis.

XPS spectra of $\mathrm{Zr}_{3 \mathrm{~d}}$ core electrons for calcined supports $\mathrm{ZrO}_{2}$, $\mathrm{ZrO}_{2}-(20 \%) \mathrm{CeO}_{2}$ and fresh reduced catalyst $\mathrm{Ag} / \mathrm{ZrO}{ }_{2}, \mathrm{Ag} / \mathrm{ZrO}_{2}-$ $(20 \%) \mathrm{CeO}_{2}$ are shown in Fig. 5. As seen in this figure, the $\mathrm{Zr}_{3 \mathrm{~d}}$ line profile can be satisfactorily fitted to two doublets whose components are $\mathrm{Zr}_{3 \mathrm{~d} \quad 5 / 2}$ and $\mathrm{Zr}_{3 \mathrm{~d} \text { 3/2 }}$. The $\mathrm{Zr}_{3 \mathrm{~d}}{ }_{5 / 2}$ feature is located near $182.2 \mathrm{eV}$ and the $\mathrm{Zr}_{3 \mathrm{~d} \text { 3/2 }}$ feature is located near $184.6 \mathrm{eV}$ for almost catalysts and supports. $\mathrm{ZrO}_{2}$ has reported BEs ranging from 181.8 to $182.3 \mathrm{eV}$. The $\mathrm{Zr}_{3 \mathrm{~d}}$ 5/2 binding energies was in a good agreement with the known data for $\mathrm{ZrO}_{2}(\mathrm{Iv}) .^{50,65-68}$

Fig. 6 shows XPS of $\mathrm{Ce}_{3 \mathrm{~d}}{ }_{5 / 2}$ and $\mathrm{Ce}_{3 \mathrm{~d}}{ }_{3 / 2}$ core levels for calcined and $\mathrm{H}_{2}$ - reduced samples. According to the literature reports, ${ }^{69-71}$ the $\mathrm{Ce}_{3 \mathrm{~d} 5 / 2}$ and $\mathrm{Ce}_{3 \mathrm{~d} 3 / 2}$ has multiplet signals being fingerprints characterizing $\mathrm{Ce}^{4+}$ and $\mathrm{Ce}^{3+}$ oxides, respectively. Compared with these data reported in the literature, we observed $\mathrm{Ce}^{4+}$ feature in the $\mathrm{ZrO}_{2}-(20 \%) \mathrm{CeO}_{2}$ and $\mathrm{Ag} / \mathrm{ZrO}_{2}-$ $(20 \%) \mathrm{CeO}_{2}$, while two weak signals from the presence of $\mathrm{Ce}^{3+}$ appeared at $903 \mathrm{eV}$ and $885 \mathrm{eV}$. Accordingly, the $\mathrm{ZrO}_{2}-(20 \%)$ $\mathrm{CeO}_{2}$ support and $\mathrm{Ag} / \mathrm{ZrO}_{2}-(20 \%) \mathrm{CeO}_{2}$ catalyst containing both $\mathrm{Ce}(\mathrm{Iv})$ and $\mathrm{Ce}(\mathrm{III})$ species. $^{\mathbf{5 8 , 5 9}}$ Damyanova et al. ${ }^{\mathbf{5 0}}$ studied $\mathrm{Pt}$ catalysts supported on pure $\mathrm{ZrO}_{2}$ and $\mathrm{CeO}_{2}-\mathrm{ZrO}_{2}$ mixed oxides with different $\mathrm{CeO}_{2}$ content through XPS. In the case of $\mathrm{Pt} / \mathrm{CeO}_{2}$, they found the $\mathrm{Ce}_{3 \mathrm{~d} 5 / 2}$ was $882.8 \mathrm{eV}$, which was characteristic of $\mathrm{CeO}_{2}$ but in the case of the catalysts containing 1-12 wt $\% \mathrm{CeO}_{2}$ were ranging from 882.2 to $882.4 \mathrm{eV}$ which were characteristic of $\mathrm{CeO}_{2}$ (IV) and $\mathrm{Ce}_{2} \mathrm{O}_{3}$ (III). Galtayries et al. ${ }^{67}$ studied $\mathrm{CeO}_{2}$ and $\mathrm{CeO}_{2}-\mathrm{ZrO}_{2}$ mixed oxides with 15, 50, 68 and 80 wt\% $\mathrm{CeO}_{2}$ through XPS. They reported $\% \mathrm{Ce}^{4+}$ for $\mathrm{CeO}_{2}$ of $70 \%$ and for $\mathrm{CeO}_{2}-\mathrm{ZrO}_{2}$ mixed oxides with 15, 50, 68 and $80 \mathrm{wt} \% \mathrm{CeO}_{2}$ of 


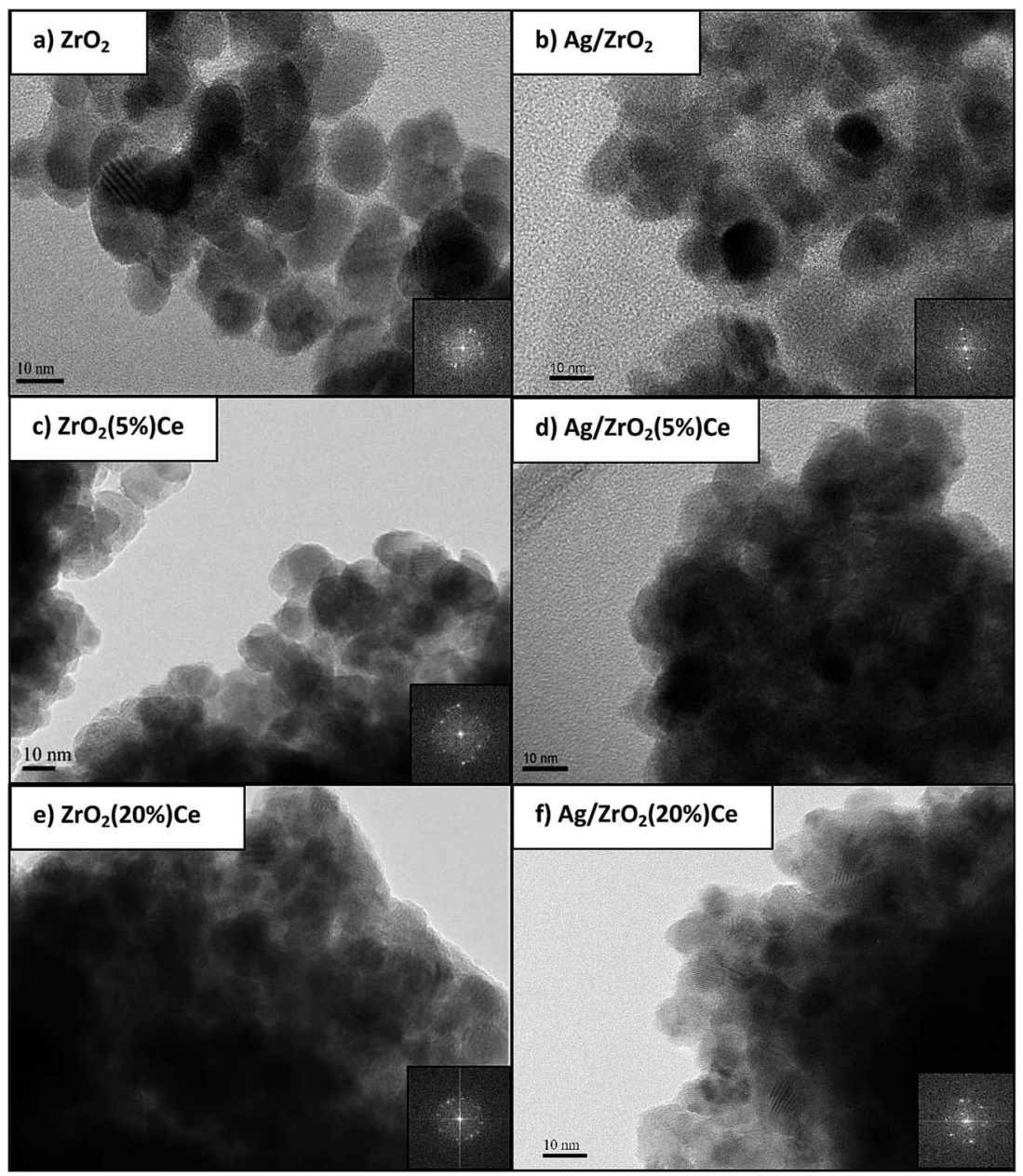

Fig. 4 TEM images for $\mathrm{ZrO}_{2}, \mathrm{ZrO}_{2}-(X \%) \mathrm{CeO}_{2}$ supports and $\mathrm{Ag} / \mathrm{ZrO} \mathrm{O}_{2}, \mathrm{Ag} / \mathrm{ZrO}_{2}-(X \%) \mathrm{CeO}_{2}$ catalysts.

Table 4 Binding energies obtained from the XPS studies (eV)

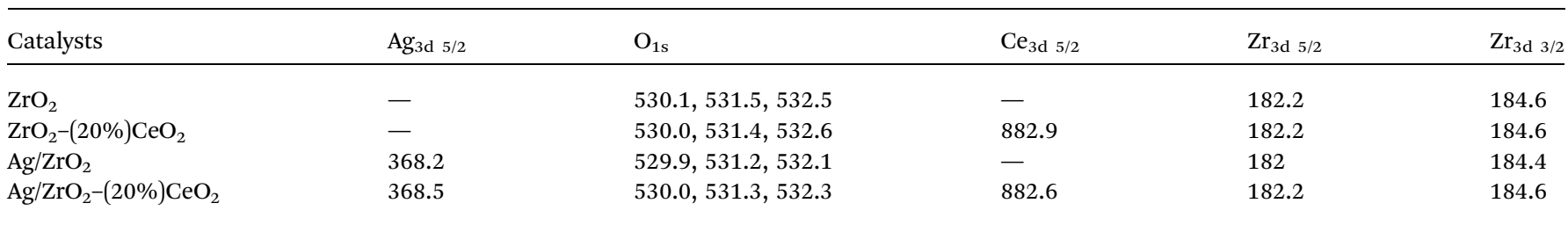

between 57 and $63 \%$. In this latter study the BEs of $\mathrm{Ce}_{3 \mathrm{~d} 5 / 2}$ for $\mathrm{CeO}_{2}-\mathrm{ZrO}_{2}$ mixed oxides (882.1 eV, $882 \mathrm{eV}, 882.1 \mathrm{eV}, 881.8 \mathrm{eV}$ ) were slightly smaller than $\mathrm{CeO}_{2}$. According to them this slightly negative shift of BEs was attributed that cerium is mainly in the $\mathrm{Ce}^{4+}$ oxidation state, with a certain increase in the $\mathrm{Ce}^{3+}$. For the samples prepared in our study, the $\mathrm{Ce}_{3 \mathrm{~d} 5 / 2}$ of $\mathrm{Ag} / \mathrm{ZrO}_{2}-(20 \%)$ $\mathrm{CeO}_{2}$ is $0.3 \mathrm{eV}$ smaller than of $\mathrm{ZrO}_{2}-(20 \%) \mathrm{CeO}_{2}$, indicating mayor abundance of $\mathrm{Ce}^{3+}$ species, after doping of silver. Derekaya et al. ${ }^{72}$ attributed the value $\mathrm{Ce}_{3 \mathrm{~d}}$ peak of $882.6 \mathrm{eV}$ for the presence of $\mathrm{Ce}(\mathrm{III})$.

Fig. 7 shows the $\mathrm{Ag}_{3 \mathrm{~d}}$ region consisted of 2 peaks which correspond to $\mathrm{Ag}_{3 \mathrm{~d} 5 / 2}$ and $\mathrm{Ag}_{3 \mathrm{~d} 3 / 2}$. The $\mathrm{Ag}_{3 \mathrm{~d} \mathrm{5/2}}$ binding energies of $\mathrm{Ag} / \mathrm{ZrO}_{2}$ and $\mathrm{Ag} / \mathrm{ZrO}_{2}-(20 \%) \mathrm{CeO}_{2}$ were $368.2 \mathrm{eV}$ and $368.5 \mathrm{eV}$ respectively. These results demonstrate that only one form of $\mathrm{Ag}$ is present, in the form of $\mathrm{Ag}^{0}$. This is because we did not observe any peak corresponding to the oxidized silver species located around $367.7 \mathrm{eV}$. The $\mathrm{Ag}_{3 \mathrm{~d}} 5 / 2$ of our samples can be compared with values were ranging from 368.1 to $368.5 \mathrm{eV}$ for metallic silver and $367.6-367.8 \mathrm{eV}$ for $\mathrm{Ag}_{2} \mathrm{O}{ }^{68,73-79}$ Thus, it is concluded from the XPS measurements that the majority of the silver ions in the nanoparticle synthesis are reduced and are in the metallic form or zero valent state for all prepared samples. Besides, there is an another important observation referred to BEs of $\mathrm{Ag}_{3 \mathrm{~d} 5 / 2}$ of our samples. For the $\mathrm{Ag} / \mathrm{ZrO}_{2}-(20 \%) \mathrm{CeO}_{2}$, the $\mathrm{BE}$ of $\mathrm{Ag}_{3 \mathrm{~d}} 5 / 2$ is $386.5 \mathrm{eV}$, which is slightly bigger than $\mathrm{Ag} / \mathrm{ZrO}_{2}$, which is $368.2 \mathrm{eV}$. Wang et al. ${ }^{77}$ studied the binding energy shift of $\mathrm{Ag}$ and $\mathrm{Au}$ supported on $\mathrm{MCM}, \mathrm{TiO}_{2}$ and $\mathrm{Al}_{2} \mathrm{O}_{3}$. They attributed such a slightly shift to the possible electron transfer from the support to the particles. Zheng et al. ${ }^{78}$ attributed the slightly shift in $\mathrm{Au}_{4 \mathrm{f}} \mathrm{BE}$ value, 


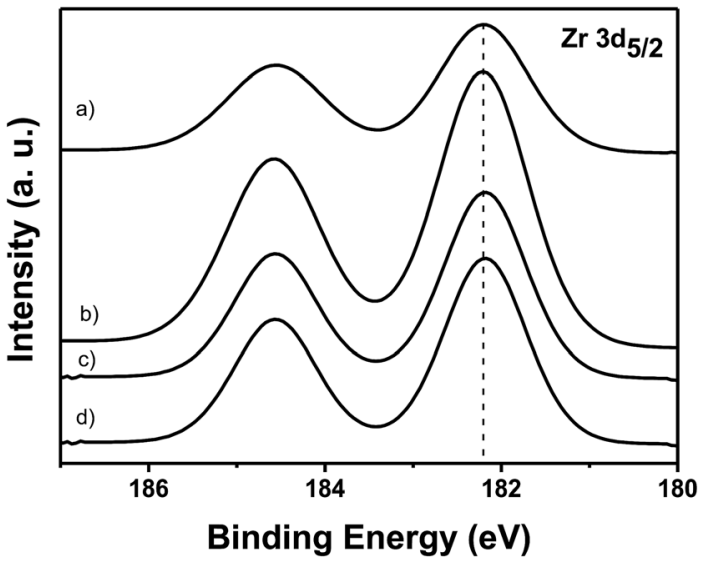

Fig. 5 XPS Zr 3d spectra for (a) $\mathrm{ZrO}_{2}-(20 \%) \mathrm{CeO}_{2}$, (b) $\mathrm{ZrO}_{2}$ supports and (c) $\mathrm{Ag} / \mathrm{ZrO}_{2}-(20 \%) \mathrm{CeO}_{2}$, (d) $\mathrm{Ag} / \mathrm{ZrO}_{2}$ catalysts.

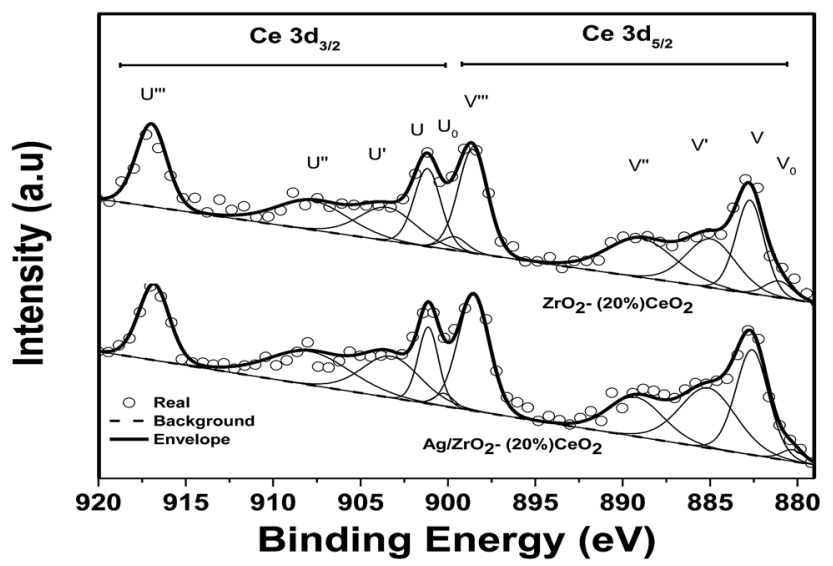

Fig. 6 XPS Ce $3 d$ spectra for $\mathrm{ZrO}_{2}-(20 \%) \mathrm{CeO}_{2}$ support and $\mathrm{Ag} / \mathrm{ZrO}_{2}-$ $(20 \%) \mathrm{CeO}_{2}$ catalyst.

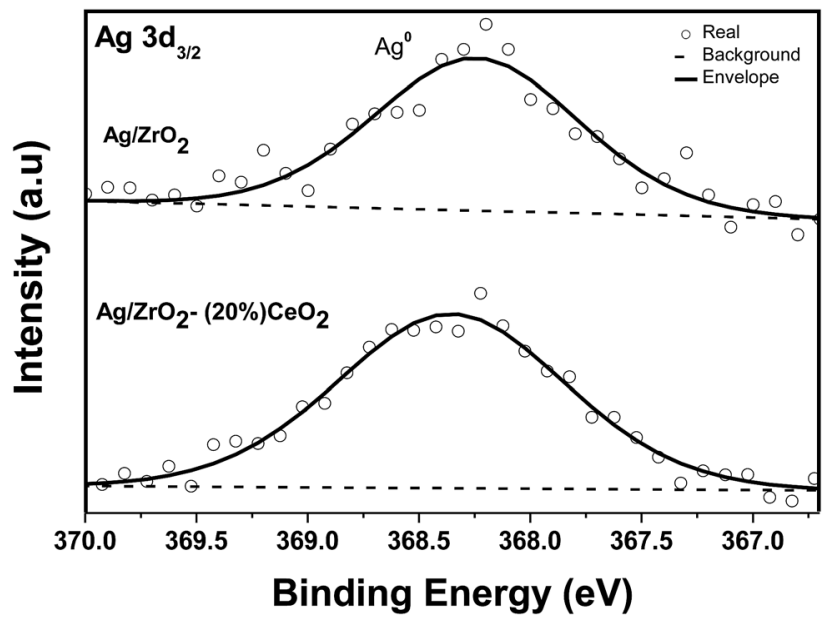

Fig. 7 XPS Ag 3d spectra for support $\mathrm{Ag} / \mathrm{ZrO}_{2}$ and $\mathrm{Ag} / \mathrm{ZrO}_{2}-(20 \%)$ $\mathrm{CeO}_{2}$ catalyst.

observed between Au/SBA-15 $(\mathrm{BE}=83.7 \mathrm{eV})$ and bulk metallic $\mathrm{Au}(\mathrm{BE}=84 \mathrm{eV})$ to the interaction between support and $\mathrm{Au}$ nanoparticles.
Hence, based on the above reports, we propose that $\mathrm{Ag}$ in $\mathrm{ZrO}_{2}$ and $\mathrm{ZrO}_{2}-(20 \%) \mathrm{CeO}_{2}$ are of a metallic nature, and $0.3 \mathrm{eV}$ difference in $\mathrm{Ag}_{3 \mathrm{~d} 5 / 2}$ we observed between those catalysts and bulk metallic silver is due to the interaction between support and Ag nanoparticles. A similar observation was already made by other investigators for the $\mathrm{Ag}$ and $\mathrm{Au}$ nanoparticles but they assigned the size and shape of metal nanoparticles are also responsible for the binding energy shift. ${ }^{77,79}$ In the case of most transition metals, upon oxidation, the observed corelevels BEs shift toward higher energies, and the positive BE shifts increase as the oxidation state increases. However, silver is one of the few examples of lowered binding energy in the oxidized state. Another discussion point implies that through $\mathrm{Ag}$ supported on $\mathrm{ZrO}_{2}-(20 \%) \mathrm{CeO}_{2}$ mixed oxides, the silver has a greater tendency to win electrons. ${ }^{74,77,78}$ This phenomenon may suggest the interaction between Ce and $\mathrm{Ag}$ as: $\mathrm{Ag}^{+}+\mathrm{Ce}^{4+} \rightarrow \mathrm{Ag}^{0}+\mathrm{Ce}^{3+}$. There was a little positive shift between this binding energy because in the case of $\mathrm{Ag} / \mathrm{ZrO}_{2}-$ $(20 \%) \mathrm{CeO}_{2}$ the binding energy is higher than $\mathrm{Ag} / \mathrm{ZrO} \mathrm{C}_{2}$ as a result of electron transfer from the support to the particle. In other words, as a result to the partial reduction of $\mathrm{CeO}_{2}$ to $\mathrm{CeO}_{2-x}$ the presence of $\mathrm{CeO}_{2}$ promotes changes in the chemical environment of silver, which it is favorable for more atoms of $\mathrm{Ag}$ to stay in a metallic state during the hydrogen pretreatment step. In addition, partial electron transfer from $\mathrm{CeO}_{2}$ to $\mathrm{Ag}_{2} \mathrm{O}$ may occur, leading to an increase in the delectron density of the surface silver atoms, which improve the catalyst performance.

XPS, UV-Vis spectrometry and TEM confirms that when ceria is present in high concentration enhance strong metal-support interaction effect.

\section{Activity tests}

Results from Fig. 8 show that the maximum activity for silver monometallic catalyst was $\mathrm{Ag} / \mathrm{ZrO}_{2}-(15 \%) \mathrm{CeO}_{2}$. This behavior can be related to several factors such as: strong metal-support interaction, high dispersion and support reducibility that influence the release of more surface oxygen atoms during the reaction. On $\mathrm{Ag} / \mathrm{ZrO}_{2}-\mathrm{CeO}_{2}$ catalysts with 5, 10, 15 and $20 \%$ ceria the MTBE conversion has values between 52 and $90 \%$, being the $\mathrm{Ag} / \mathrm{ZrO}_{2}-(15 \%) \mathrm{CeO}_{2}$ catalyst the most active with $90 \%$ MTBE conversion. This latter catalyst had also the highest metallic dispersion. It can be concluded that there is a relationship between the crystal size of support and the metallic dispersion of silver that lead an improved catalytic performance. On the other hand, the complete catalytic oxidation of MTBE yields $\mathrm{CO}_{2}$ and $\mathrm{H}_{2} \mathrm{O}$ as final products. However, if the mineralization is not totally completed some intermediates can be formed. This latter phenomenon produces issues in the efficient of the process. The reaction pathway of MTBE catalytic oxidation has been extensively reported in the literature ${ }^{15,16}$ where different compounds such as methanol, isopropyl alcohol, tert-butyl alcohol and acetone have been identified as intermediates products of the MTBE catalytic oxidation reaction. The intermediate identified in the present work was acetone. 


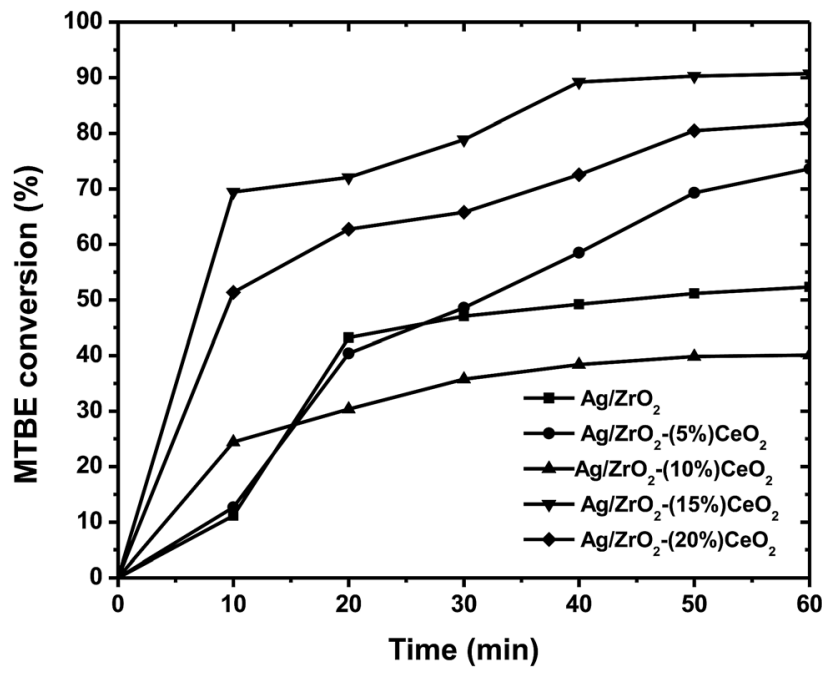

Fig. 8 MTBE conversions as a function of the time for silver supported catalysts.

According to the results in Table 5 it is possible to analyze that in a TOC conversion between 69 and $80 \%$ and in a conversion of MTBE between 82 and $90 \%$ there is no presence of acetone, this lead to infer that there is a possible catalytic oxidation almost complete for silver catalysts supported with higher content of ceria.

In TOC conversion for monometallic catalysts (Fig. 9) it is strongly distinguished the effect of ceria dopant on the conversion of intermediates, because at a high content of cerium oxide (15 to $20 \%$ ) it results in high percentages of TOC conversion (69 and $80 \%$ ), so the reaction rate is faster for the conversion of intermediates and therefore, the concentration of the intermediate compounds is degraded more efficiently. According to the reported by Cervantes et al. ${ }^{16}$ this latter result is controlled by the relative abundance of $\mathrm{Ce}^{4+}$.

It is generally accepted that the oxidation reactions over mixed oxide catalyst proceed according to the redox model proposed by Mars and van Krevelen. ${ }^{83}$ Based on their findings, the following reactions are proposed to explain the effect of the partial reduction of ceria on metallic silver:

(1) Oxygen is adsorbed in oxygen vacant site over ceria surface lattice.

$$
\mathrm{Ce}^{3+}-\mathrm{V}_{\mathrm{O}}+\mathrm{O}_{2} \rightarrow \mathrm{Ce}^{4+}-\mathrm{O}_{2}{ }^{-}+\mathrm{H}_{2} \mathrm{O}\left(\mathrm{V}_{\mathrm{O}} \text { : oxygen vacant }\right)
$$

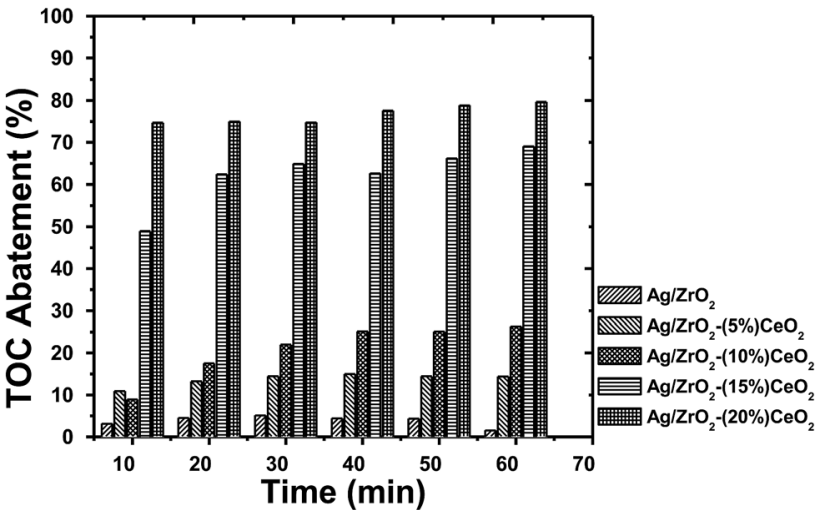

Fig. 9 TOC abatement as a function of the time for silver supported catalysts.

(2) The partial reduction of ceria is reversible because of oxygen adsorbed in oxygen vacancy as a result $\mathrm{Ag}^{0}$ becomes $\mathrm{Ag}^{+}$.

$$
\mathrm{Ag}^{0}+\mathrm{Ce}^{4+}-\mathrm{O}_{2}^{-} \rightarrow \mathrm{Ce}^{3+}-\mathrm{V}_{\mathrm{O}}+\mathrm{O}_{2}^{-}+\mathrm{Ag}^{+}
$$

(3) $\mathrm{Ag}^{+}$attack MTBE for the conversion to $\mathrm{CO}_{2}+\mathrm{H}_{2} \mathrm{O}$.

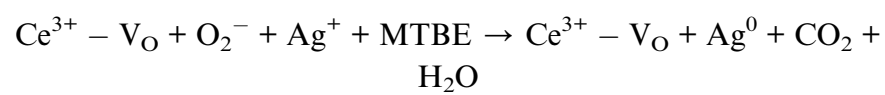

It is known that oxygen vacancies of zirconia-ceria support play an important role in the dispersion of silver. These oxygen vacancies are the result of anionic deficiencies that reduce $\mathrm{Ce}^{4+}$ to $\mathrm{Ce}^{3+}$. Then, this process of self-reduction can be accelerated by the addition of silver that attacks the weak ceria surface oxygen bond allowing their release from the support lattice. Decreasing the zirconia-ceria support crystal size leads to the formation of higher number of surface oxygen and therefore a higher number of metallic silver active sites. Furthermore, the ratio between the crystal size and oxygen vacancies can influence the amount of silver atoms that can be deposited on the support. Greater metal dispersion was found at higher ceria content (i.e. 15 and 20\%) because the total oxygen vacancies of the catalyst support depend on ceria loading. ${ }^{80}$ The oxygen vacancies are acid sites called Lewis sites where a nucleophilic

Table 5 Activity and selectivity for the catalyst wet-air oxidation of MTBE after 60 min of reaction. MTBE conversion $\left(X_{C}\right)$, TOC abatement $\left(X_{\text {TOC }}\right)$

\begin{tabular}{|c|c|c|c|c|c|}
\hline Catalysts & $X_{\mathrm{C}}^{a}(\%)$ & $X_{\text {TOC }}{ }^{a}(\%)$ & $A^{a}\left(\mathrm{mmol} \mathrm{l}^{-1}\right)$ & $r_{1}^{a}\left(\mathrm{mmol} \mathrm{h}^{-1} \mathrm{~g}_{\mathrm{met}}^{-1}\right)$ & Selectivity to $\mathrm{CO}_{2}{ }^{a}$ \\
\hline $\mathrm{Ag} / \mathrm{ZrO}_{2}$ & 52 & 10 & 24 & 1560 & 19 \\
\hline $\mathrm{Ag} / \mathrm{ZrO}_{2}-(5 \%) \mathrm{CeO}_{2}$ & 73 & 14 & 4 & 2190 & 19 \\
\hline $\mathrm{Ag} / \mathrm{ZrO}_{2}-(15 \%) \mathrm{CeO}_{2}$ & 90 & 69 & n.d. & 2700 & 77 \\
\hline $\mathrm{Ag} / \mathrm{ZrO}_{2}-(20 \%) \mathrm{CeO}_{2}$ & 82 & 80 & n.d. & 2400 & 98 \\
\hline
\end{tabular}
and intermediate concentration (acetone) as a function of the time for silver supported catalysts

${ }^{a}$ Obtained after $1 \mathrm{~h}$ of reaction n.d. $=$ not detected. 


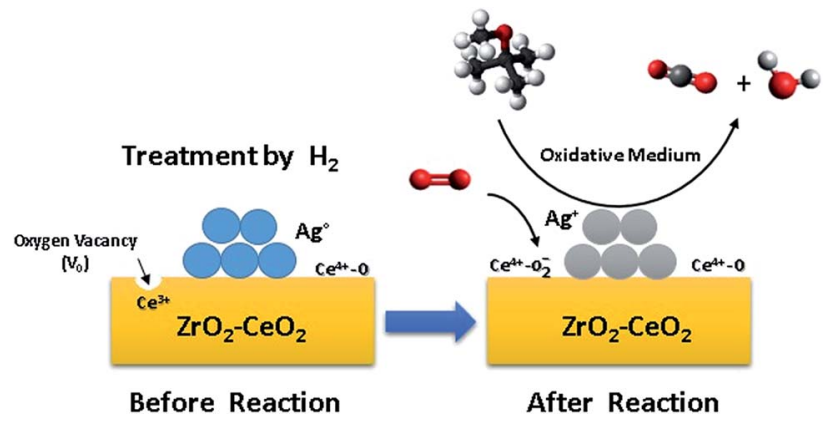

Fig. 10 Scheme proposed to explain the effect of the partial reduction of ceria on metallic silver to destroy MTBE by CWAO.

substrate can be deposited. During the oxidation reaction it is known that superoxide species $\left(\mathrm{O}^{2-}\right)$ are formed on a partially reduced $\mathrm{CeO}_{2}$ surface as a result of the present of free electrons. $^{21}$

Small crystal size of zirconia-ceria support interacts with Ag more strongly, so that the reactivity of catalyst was enhanced (Fig. 10).

\section{Conclusions}

From the study it can be concluded by the use of the deposition-precipitation method it is possible the homogeneous incorporation of low amount of $\mathrm{Ag}$ to the tetragonal $\mathrm{ZrO}_{2}-$ $\mathrm{CeO}_{2}$ and monoclinic-tetragonal $\mathrm{ZrO}_{2}$ lattice. It was also found that $\mathrm{CeO}_{2}$ is a structural promoter for silver on $\mathrm{ZrO}_{2}$ because it can improve the dispersion of silver on the catalyst support and possibly inhibit the sintering of silver during the reaction. On the other hand, zirconia tetragonal phase ( $t-$ $\mathrm{ZrO}_{2}$ ) stability was also enhanced by $\mathrm{CeO}_{2}$ addition, meanwhile its mean crystallite size was diminished according to DRX and TEM results. $\mathrm{CeO}_{2}$ is an electronic promoter for silver over $\mathrm{ZrO}_{2}$ as it can chance the chemical environment by preventing silver to oxidize due to an increase the d-electron density of the surface silver atoms. These results were confirmed for the monometallic catalyst with the highest ceria content.

Through XPS, UV-Vis spectrometry and TEM should be clearly seen that the highest ceria content promotes strong metal support interaction.

Indeed, small zirconia crystal size produce high silver metal dispersion because of the electron transfer from ceria in the lattice of zirconia to silver and as a collateral effect the improvement in the effectiveness of MTBE oxidation catalytic reaction. As a result, $\mathrm{ZrO}_{2}-\mathrm{CeO}_{2}$ is an active support and can enhance the activity of MTBE catalytic wet air oxidation. Catalyst $\mathrm{Ag} / \mathrm{ZrO}_{2}-(15 \%) \mathrm{CeO}_{2}$ was the most active catalyst in the conversion of MTBE with $90 \%$. However, TOC conversion reached $80 \%$ for the catalyst $\mathrm{Ag} / \mathrm{ZrO}_{2}-(20 \%) \mathrm{CeO}_{2}$, presenting a higher selectivity to $\mathrm{CO}_{2}$ with $98 \%$, therefore is the most active for CWAO reaction of MTBE mineralizing intermediaries in a more efficient way.

\section{Acknowledgements}

We thank CONACYT by finance support of the project 132648 and by scholarship of M.Sc. to Zenaida Guerra Que, who in addition thank CONACYT and the Universidad Juárez Autónoma de Tabasco for financial support to achieve a stay of international mobility in the Queensland University at the ARC Centre of Excellence for Functional Nanomaterials, the Australian Institute for Bioengineering and Nanotechnology (AIBN).

\section{References}

1 G. Li, T. An, J. Chen, G. Sheng, J. Fu, F. Chen, S. Zhang and H. Zhao, J. Hazard. Mater., 2006, 138, 392-400.

2 A. Rossner and D. R. U. Knappe, Water Res., 2008, 42, 22872299.

3 J. M. Britto, S. B. de Oliveira, D. Rabelo and M. do C. Rangel, Catal. Today, 2008, 133-135, 582-587.

4 M. F. Dignac, P. Ginestet, D. Rybacki, A. Bruchet, V. Urbain and P. Scribe, Water Res., 2000, 34, 4185-4194.

5 Q. Li, C. Kang and C. Zhang, Process Biochem., 2005, 40, 873877.

6 M. van Afferden, K. Z. Rahman, P. Mosig, C. De Biase, M. Thullner, S. E. Oswald and R. A. Müller, Water Res., 2011, 45, 5053-5074.

7 J. C. Campos, R. M. H. Borges, A. M. Oliveira Filho, R. Nobrega and G. L. Sant'Anna, Water Res., 2002, 36, 95104.

8 D. P. Lince, L. R. Wilson and G. A. Carlson, Bull. Environ. Contam. Toxicol., 1998, 61, 484-488.

9 L. Toran, C. Lipka, A. Baehr, T. Reilly and R. Baker, Water Res., 2003, 37, 3756-3766.

10 T. C. Schmidt, S. B. Haderlein, R. Pfister and R. Forster, Water Res., 2004, 38, 1520-1529.

11 A. Kolb and W. Püttmann, Water Res., 2006, 40, 3551-3558.

12 A. Safarzahed-Amiri, Water Res., 2001, 35, 3706-3714.

13 J. Sutherland, C. Adams and J. Kekobad, Water Res., 2004, 38, 193-205.

14 I.-P. Chen, S.-S. Lin, C.-H. Wang, L. Chang and J.-S. Chang, Appl. Catal., B, 2004, 50, 49-58.

15 I. Cuauhtémoc, G. Del Angel, G. Torres, J. Navarrete, C. Angeles-Chavez and J. M. Padilla, J. Ceram. Process. Res., 2009, 10, 512-520.

16 A. Cervantes, G. Del Angel, G. Torres, G. Lafaye, J. Barbier Jr, J. N. Beltramini, J. G. Cabañas-Moreno and A. Espinoza de los Monteros, Catal. Today, 2013, 212, 2-9.

17 U. Hübner, U. von Gunten and M. Jekel, Water Res., 2015, 68, 150-170.

18 J. Barbier Jr, F. Delano, F. Jabouille, D. Duprez, G. Blanchard and P. Isnardz, J. Catal., 1998, 177, 378-385.

19 J. Gaálováa, J. Barbier Jr and S. Rossignol, J. Hazard. Mater., 2010, 181, 633-639.

20 Q. Liu, Y. Cao, W.-L. Dai and J.-F. Deng, Catal. Lett., 1998, 55, 87-91.

$21 \mathrm{Lj}$. Kundakovic and M. Flytzani-Stephanopoulos, Appl. Catal., A, 1999, 183, 35-51. 
22 D. Chen, Z. Qu, S. Shen, X. Li, Y. Shi, Y. Wang, Q. Fu and J. Wu, Catal. Today, 2011, 175, 338-345.

23 R. Zhang and S. Kaliaguine, Appl. Catal., B, 2008, 78, 275287.

24 Z. Qu, M. Cheng, W. Huang and X. Bao, J. Catal., 2005, 229, 446-458.

25 G. V. Mamontov, T. I. Izaak, O. V. Magaev, A. S. Knyazev and O. V. Vodyankina, Russ. J. Phys. Chem. A, 2011, 85, 15401545.

26 T. Nanba, S. Masukawa, A. Abe, J. Uchisawa and A. Obuchi, Appl. Catal., B, 2012, 123-124, 351-356.

$27 \mathrm{Lj}$. Kundakovic and M. Flytzani-Stephanopoulos, J. Catal., 1998, 179, 203-221.

28 M. Nolan, S. C. Parker and G. W. Watson, Surf. Sci., 2005, 595, 223-232.

29 S. P. Badwal, D. Fini, F. T. Ciacchi, C. Munnings, J. A. Kimpton and J. Drennan, J. Mater. Chem. A, 2013, 1, 10768-10782.

30 Y. Kang, M. Sun and A. Li, Catal. Lett., 2012, 142, 1498-1504.

31 N. Shehata, K. Meehan, M. Hudait and N. Jain, J. Nanopart. Res., 2012, 14, 1-10.

32 J. A. Montoya, E. Romero-Pascual, C. Gimon, P. Del Angel and A. Monzón, Catal. Today, 2000, 63, 71-85.

33 S. S. Lin, D. J. Chang, C.-H. Wang and C. C. Chen, Water Res., 2003, 37, 793-800.

34 R. Hyun-Seog, W. Yong and D. L. King, Top. Catal., 2008, 49, 32-37.

35 D. Weng, J. Li, X. Wu and Z. Si, J. Environ. Sci., 2011, 23, 145150.

36 P. López, G. Mondragón-Galicia, M. E. Espinosa-Pesqueira, D. Mendoza-Anaya, Ma. E. Fernández, A. Gómez-Cortés, J. Bonifacio, G. Martínez-Barrera and R. Pérez-Hernández, Int. J. Hydrogen Energy, 2012, 37, 9018-9027.

37 A. V. González, X. Karatzas and L. J. Pettersson, Fuel, 2013, 107, 162-169.

38 X.-R. Chen, Y.-H. Ju and C.-Y. Mou, J. Phys. Chem. C, 2007, 111, 18731-18737.

39 F. Menegazzo, P. Burti, M. Signoretto, M. Manzoli, S. Vankova, F. Boccuzzi, F. Pinna and G. Strukul, J. Catal., 2008, 257, 369-381.

40 L. Meng, L. Liu, X. Zi, H. Dai, Z. Zhao, X. Wang and H. He, Front. Environ. Sci. Eng. China, 2010, 4, 164-171.

41 A. L. Quinelato, E. Longo, E. R. Leite, M. I. B. Bernardi and J. A. Varela, J. Mater. Sci., 2001, 36, 3825-3830.

42 R. M. Navarro, M. C. Álvarez-Galván, F. Rosa and J. L. G. Fierro, Appl. Catal., A, 2006, 297, 60-72.

43 V. Dhanala, S. K. Maity and D. Shee, $R S C A d v ., 2015,5$, 52522-52532.

44 J. Mikulova, J. Barbier Jr, S. Rossignol, D. Mesnard, D. Duprez and C. Kappenstein, J. Catal., 2007, 251, 172-181.

45 K.-i. Shimizu, H. Kawachi, K. S.-i. Komai, K. Yoshida, Y. Sasaki and A. Satsuma, Catal. Today, 2011, 175, 93-99.

46 N. A. Saidina Amin and C. M. Chong, Chem. Eng. J., 2005, 113, 13-25.

$47 \mathrm{~W}$. Khaodee, N. Tangchupong, B. Jongsomjit, P. Praserthdam and S. Assabumrungrat, Catal. Commun., 2009, 10, 494-501.
48 J. A. Montoya, E. Romero-Pascual, C. Gimon, P. Del Angel and A. Monzón, Catal. Today, 2000, 63, 71-85.

49 V. Raju, S. Jaenicke and G.-K. Chuah, Appl. Catal., B, 2009, 91, 92-100.

50 S. Damyanova, B. Pawelec, K. Arishtirova, M. V. Martinez Huerta and J. L. G. Fierro, Appl. Catal., B, 2009, 89, 149-159.

51 R. Pérez-Hernández, A. Gutiérrez-Martínez, J. Palacios, M. Vega-Hernández and V. Rodríguez-Lugo, Int. J. Hydrogen Energy, 2011, 36, 6601-6608.

52 V. Solinas, E. Rombi, I. Ferino, M. G. Cutrufello, G. Colón and J. A. Navío, J. Mol. Catal. A: Chem., 2003, 204-205, 629635.

53 G. Postole, B. Chowdhury, B. Karmakar, K. Pinki, J. Banerji and A. Auroux, J. Catal., 2010, 269, 110-121.

54 C. F. Oliveira, F. A. C. Garcia, D. R. Araujo, J. L. Macedo, S. C. L. Dias and J. A. Dias, Appl. Catal., A, 2012, 413-414, 292-300.

55 S. Xu and X. Wang, Fuel, 2005, 84, 563-567.

56 J. Guo, Z. Shi, D. Wu, H. Yin, M. Gong and Y. Chen, Mater. Res. Bull., 2013, 48, 495-503.

57 D. Mukherjee, B. G. Rao and B. M. Reddy, Appl. Catal., B, 2016, 197, 105-115.

58 L. Zhang, L. Pan, C. Ni, T. Sun, S. Zhao, S. Wang, A. Wang and Y. Hu, Int. J. Hydrogen Energy, 2013, 38, 4397-4406.

59 Z. Si, D. Weng, X. Wu, Z. Ma, J. Ma and R. Ran, Catal. Today, 2013, 201, 122-130.

60 Q. Yu, X. Wu, X. Yao, B. Liu, F. Gao, J. Wang and L. Dong, Catal. Commun., 2011, 12, 1311-1317.

61 G. Ranga Rao and B. Gopal Mishra, Bull. Catal. Soc. India, 2003, 2, 122-134.

62 A. Franceschetti, S. J. Pennycook and S. T. Pantelides, Chem. Phys. Lett., 2003, 374, 471-475.

63 X. Zheng, Q. Zhang, Y. Guo, W. Zhan, Y. Guo, Y. Wang and G. Lu, J. Mol. Catal. A: Chem., 2012, 357, 106-111.

64 M. Vicario, J. Llorca, M. Boaro, C. Leitenburg and A. Trovarelli, J. Rare Earths, 2009, 27, 196-203.

65 J. Lin, H. Y. Chen, L. Chen, K. L. Tan and H. C. Zeng, Appl. Surf. Sci., 1996, 103, 307-314.

66 S. D. Jones, L. M. Neal, M. L. Everett, G. B. Hoflund and H. E. Hagelin-Weaver, Appl. Surf. Sci., 2010, 256, 7345-7353.

67 A. Galtayries, R. Sporken, J. Riga, G. Blanchard and R. Caudano, J. Electron Spectrosc. Relat. Phenom., 1998, 8891, 951-956.

68 J. F. Moulder, W. W. Stickle, P. E. Sobol and K. D. Bomber, Handbook of X-ray photoelectron spectroscopy, ed. J. Chastain, Perkin Elmer, Eden Praine, U.S.A, 1978.

69 E. Abi-aad, R. Bechara, J. Grimblot and A. Aboukaïs, Chem. Mater., 1993, 5, 793-797.

70 N. Liu, Z. Yuan, C. Wang, S. Wang, C. Zhang and S. Wang, Fuel Process. Technol., 2008, 89, 574-581.

71 R. Ran, J. Fan and D. Weng, Prog. Nat. Sci.: Mater. Int., 2012, 22, 7-14.

72 F. B. Derekaya and C. Güldür, Int. J. Hydrogen Energy, 2010, 35, 2247-2261.

73 H. Li, X. Duan, G. Liu and X. Liu, J. Mater. Sci., 2008, 43, 1669-1676. 
74 P. Sangpour, O. Akhavan and A. Z. Moshfegh, J. Alloys Compd., 2009, 486, 22-28.

75 X.-Y. Gao, S.-Y. Wang, J. Li, Y.-X. Zheng, R.-J. Zhang, P. Zhou, Y.-M. Yang and L.-Y. Chen, Thin Solid Films, 2004, 455-456, 438-442.

76 A. Zielinska-Jurek, E. Kowalska, J. W. Sobczak, W. Lisowski, B. Ohtani and A. Zaleska, Appl. Catal., B, 2011, 101, 504-514.

77 A.-Q. Wang, J.-H. Liu, S. D. Lin, T.-S. Lin and C.-Y. Mou, J. Catal., 2005, 233, 186-197.
78 J. Zheng, H. Lin, Y.-n. Wang, X. Zheng, X. Duan and Y. Yuan, J. Catal., 2013, 297, 110-118.

79 X. Huang, X. Wang, X. Wang, X. Wang, M. Tan, W. Ding and X. Lu, J. Catal., 2013, 301, 217-226.

80 H. C. Yao and Y. F. Yu Yao, J. Catal., 1984, 86, 254-265.

81 A. Sandoval, A. Aguilar, C. Louis, A. Traverse and R. Zanella, J. Catal., 2011, 281, 40-49.

82 L. Zhang, D. Xia and Q. Shen, J. Nanopart. Res., 2006, 8, 2328.

83 P. Mars and D. W. van Krevelen, Chem. Eng. Sci., 1954, 3, 41. 